\title{
Going with the flow
}

\author{
James Edmund Sarkodieh, ${ }^{1}$ Mark A Samaan ${ }_{1}{ }^{2}$ Arman Parsai ${ }^{1}$
}

${ }^{1}$ Department of Radiology, Barts Health NHS Trust, London, England, UK ${ }^{2}$ Department of Hepatology, Barts Health NHS Trust, London, UK

\section{Correspondence to} Dr James Edmund Sarkodieh, james.sarkodieh@ doctors.org.uk
To cite: Sarkodieh JE, Samaan MA, Parsai A. BMJ Case Reports Published online: 4 December 2012 doi:10.1136/bcr-2012 007674

\section{DESCRIPTION}

As part of a routine assessment for liver transplantation, a 48-year-old gentleman with cirrhosis secondary to hepatitis $\mathrm{C}$ (genotype $2 \mathrm{~b}$ ) underwent
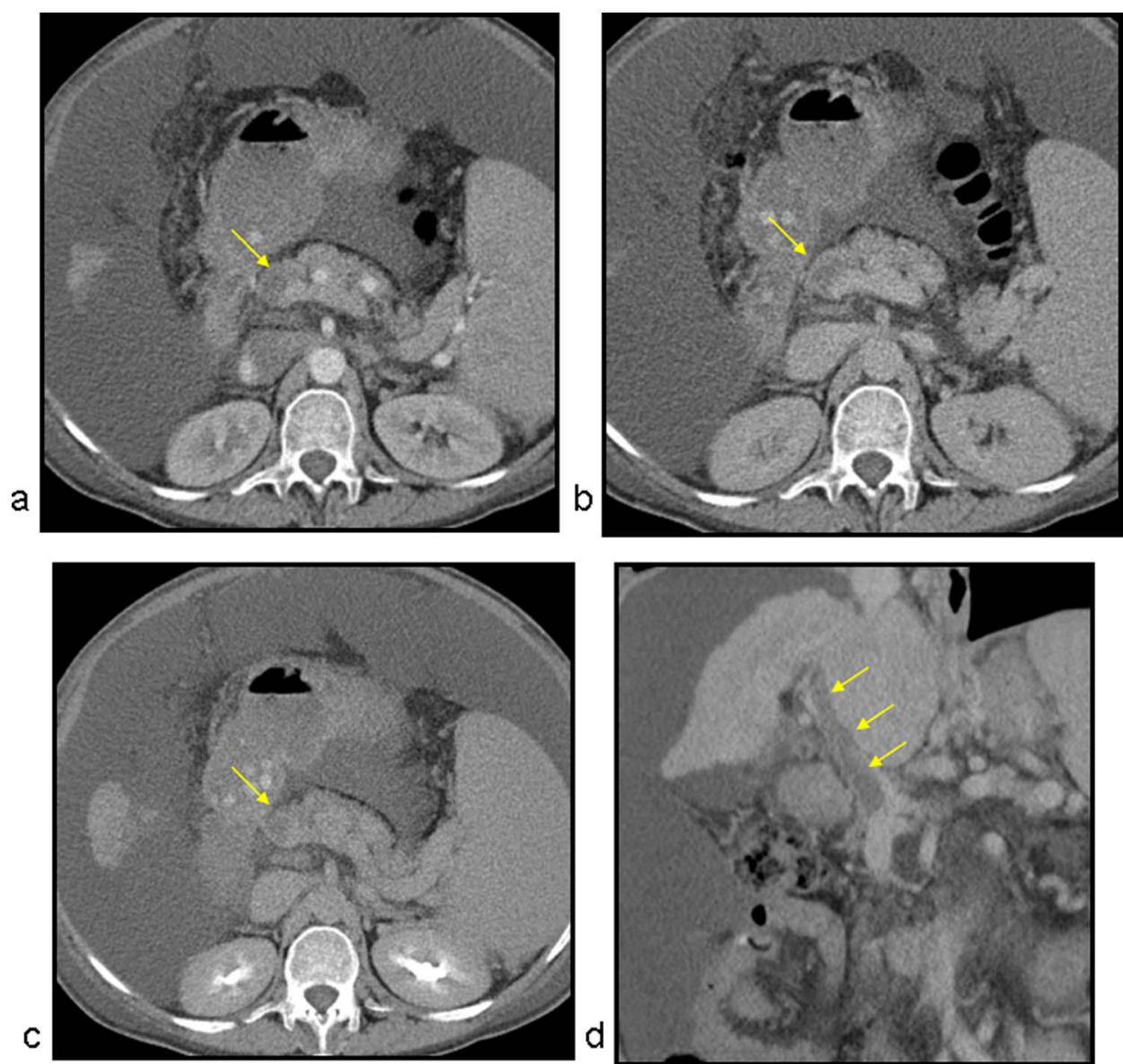

Figure 1 Axial plane triple phase CT liver examination demonstrates a hypodense main portal vein (arrows) proximal to the confluence of the splenic and superior mesenteric veins (A) arterial phase (B) portovenous phase (C) delayed phase (D) coronal plane portovenous phase (note large volume ascites).

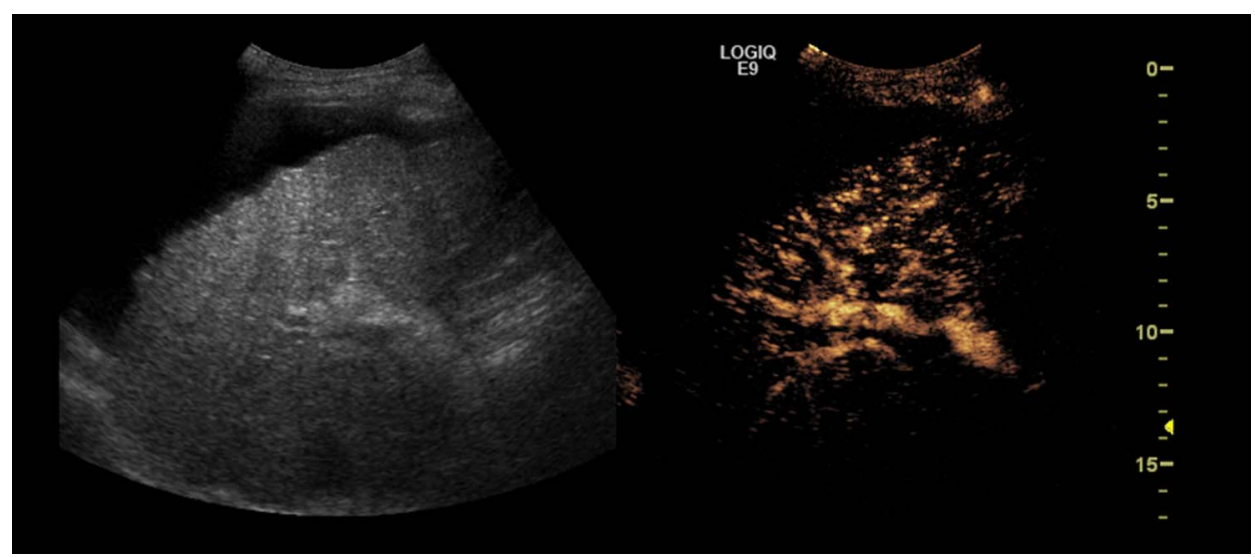

Figure 2 Left: the grey-scale ultrasound shows a coarsened liver echotexture with a nodular outline and ascites in keeping with cirrhosis. Right: contrast microbubble enhanced liver ultrasound shows portal vein opacification. No portal vein thrombus identified. 
liver disease score (UKELD of 57). He had also had two previous episodes of variceal bleeding necessitating band ligation and stays in intensive care.

A triple phase liver CT showed liver cirrhosis and ascites. It also identified a hypodense appearance of the main portal vein extending into the right and left main branches, believed to represent a large filling defect (figure 1). Consequently, the diagnosis of portal vein thrombosis was made. This condition has an increased incidence in patients with liver cirrhosis and is a relative contraindication to liver transplantation.

Soon after this, the patient was referred for ultrasound-guided drainage of his tense ascites. As part of the initial assessment, the portal vein was noted to be patent. No thrombus was identified. To further investigate this unexpected finding, a contrast ultrasound study using intravenous sulphur hexafluoride microbubbles, confirmed good portal vein opacification and no thrombus (figure 2). The patient had not been anticoagulated between the CT and ultrasound scan which were 4 weeks apart. The patient remained on the liver transplant waiting list.

\section{Learning points}

- Opacification of the portal vein on CT relies on normal hepatopetal flow of contrast from splanchnic circulation and normal portal venous blood pressure. ${ }^{12}$

- In patients with liver cirrhosis and portal venous hypertension, large filling defects in the portal vein on CT could represent flow artifacts or thrombus. Differentiation between these entities using US Doppler or contrast-enhanced US is important as it alters the management.

Competing interests None.

Patient consent Obtained.

\section{REFERENCES}

1 Reinig JW, Sanchez FW, Vujic I. Hemodynamics of portal blood flow shown by CT portography. Work in progress. Radiology 1985;154:473-6.

2 Bryce TJ, Yeh BM, Qayyum A, et al. CT signs of hepatofugal portal venous flow in patients with cirrhosis. AJR Am J Roentgenol 2003;181:1629-33.

\footnotetext{
Copyright 2012 BMJ Publishing Group. All rights reserved. For permission to reuse any of this content visit http://group.bmj.com/group/rights-licensing/permissions.

BMJ Case Report Fellows may re-use this article for personal use and teaching without any further permission.

Become a Fellow of BMJ Case Reports today and you can:

- Submit as many cases as you like

- Enjoy fast sympathetic peer review and rapid publication of accepted articles

- Access all the published articles

- Re-use any of the published material for personal use and teaching without further permission

For information on Institutional Fellowships contact consortiasales@bmjgroup.com

Visit casereports.bmj.com for more articles like this and to become a Fellow
} 